\title{
TURKISH HUMANISM AND THE POETRY OF YUNUS EMRE
}

\author{
Talât Sait HALMAN \\ (İstanbul)
}

Humanism has been an abiding tradition in Turkish culture from the earliest times until the present day. Before settling in Anatolia and conversion to Islam, Turks had already acquired humanistic attitudes as a result of the vicissitudes they experienced in long periods of exodus and brief sojourns - -changes of locale, shifting cultural orientation, new religious affiliations, warfare against many nations and communities, struggle for survival in the face of natural disasters -all of which created a sense of life's impermanency as well as the concept of the human element withstanding the ravages of a hostile world. Contact with diverse peoples gave the Turks a faculty for easy intercourse based on latitudinarian views. Cataclysmic social and cultural changes instilled in them a sense of confidence in the human value rather than reliance on institutions.

These patterns of humanism which the Turks brought with them found fertile ground in the intellectual ferment of Anatolia. After centuries of Judaeo-Christian humanistic mysticism, Islamic mysticism, as formulated and propagandized by Persian thinkers and poets, had firmly established itself in many parts of the Moslem world. As the Turks accepted the Islamic faith and absorbed its cultural concomitants, which had been evolved by the Arabs and the Persians, they found in the sufi tradition many concepts of humanism congenial to their pre-Islamic humanistic attitudes.

By the late 13th Century, Islamic mysticism- -particularly the sufi philosophy of Mevlana Celaleddin Rumi- -had been flourishing in Anatolia. After several centuries of turmoil in the new homeland of the Turks- -with the ravages of the Crusades, the Byzantine-Seldjouk wars, the Mongol invasions, and strife among various Anatolian states and principalities still visible- there was a craving for peace based on an appreciation of man's inherent worth. Mysticism, which attributed God-like qualities to man, became the apostle of peace and the chief defender of the value of man. While 
the ghazi spirit still served as the primary impetus to Turkish conquests, the intellectual tradition of mysticism, with its eentral concern for man's dignity and worth, formed an antithetical, if not antagonistic, alternative to warfare and to inter-religious strife as well as intra-religious sectarianism. The humanistic mysticism of Anatolia in the late 13th century, with its concern for peace, brotherhood, man's intrinsic significance and humanitarianism, was the culmination -better still, the perfection- of the incipient humanism which the Turks brought with them to Anatolia.

The tradition of Turkish humanism is best represented by Yunus Emre. His poetry embodied the quintessence of Turkish-Anatolian- Islamic humanism and served as a fountainhead of the humanistic concepts which were also at work, overtly or implicitly, in the intellectual life of the Turks in later centuries. $\left({ }^{*}\right)$

Yunus Emre (d. ca. 1320) was the most significant literary figure of Turkish Anatolia to assimilate the teachings of Islam and to forge a synthesis whereby the primary values of Islamic theology were merged into a body of mystic folk poetry which used indigenous Turkish verse-forms and the vernacular readily intelligible to the uneducated Turks of his day and which stressed the importance of humanistic and humanitarian values and regarded Islam not in terms of rigid formulas but in terms of freedom of the conscience and fundamental ethos.

His abiding faith was humanism, the system of thought which exalts man in his relations with God, nature and society. The humanist accepts man as the criterion of creation, but the dogma of many major religions, including Islam, argues that man's existence on earth is devoid of significance or value. Yunus Emre-the first great figure of Turkish humanism-stood squarely against Moslem dogmatists in expressing the primary importance of human existence:

I see my moon right here on earth

What would I do with all the skies?

My eyes are on this ground from where

The rains of mercy come down on me.

* There are no systematic studies of Turkish humanism. Intimations of early humanistic concepts will be found in treatises on the mystic tradition and specifically on Mevlana Celâleddin Rumi and Yunus Emre, and in several excellent surveys of Seldjouk gistory written by Prof. Osman Turan, Prof. Mehmet Altay Köymen, Prof. tbrahim Kafesoğlu et al. 
This is not a repudiation of a transcendent God. Rather, it is the internalization or humanization of God. The religious establishment in Yunus Emre's day was preaching scorn for the human being, propagating a sense of the futility of earthly existence. In open defiance of this teaching, Yunus Emre posited an image of man not as an outcast, but as an extension of Gcd's reality and love:

\section{We love the created \\ For the Creator's sake}

Yunus Emre recognized love as the celebration of life and denounced the warring spirit that had inflicted such devastation and havoc on his land and epoch:

I am not here on earth for strife,

Love is the mission of my life.

Suffused through the verses of Yunus Emre is the concept of love as the supreme attribute of man and God:

When love arrives, all needs and flaws are gone.

$\mathrm{He}$ found in love a spiritual force which transcends the narrow confines into which human beings are forced:

The man who feels the marvels of true love

Abandons his religion and nation.

As a true mystic, he went in search of God's essence and, after sustained struggle and anguish, made his ultimate discovery:

The Providence that casts this spell And speaks so many tongues to tell.

Transcends the earth, heaven and hell,

But is contained in this heart's cast.

The yearning formented my mind.

I searched the heavens and the ground;

I looked and looked, but failed to find.

I found Him inside man at last.

This faith in the primacy of man prompted the mystic poet to remind the orthodox adherents of the faith in the following terms: 
You better seek your God right in your own heart;

$\mathrm{He}$ is neither in the Holy Land nor in Mecca.

Yunus Emre had a pantheistic concept of God and naturalistic and ecumenical visions as well:

With the mountains and rocks

I call you out, my God;

With the birds as day breaks

I call you out, my God.

With Jesus in the sky.

Moses on Mount Sinai,

Raising my sceptre high,

I call you out, my God.

The mystic poet spurned book learning if it did not have humanistic relevance, because, unlike Moslem dogmatists, he believed in the godliness of men:

If you don't see man as God.

All your learning is useless.

Yunus Emre's poetry has remained alive, as an integral part of the oral tradition of folk poetry, in the heartland of Turkish Anatolia. He is the greatest figure in the long history of Turkish poetry. In his own age, and in later centuries, even to the present day, he provided spiritual guidance and aesthetic enjoyment. Perhaps more significantly, he courageously spoke out against the oppression of the poor and underprivileged people by the rulers, landowners, wealthy men, officials, and religious leaders:

Kindness of the lords ran its course,

Now each one goes straddling a horse,

They eat the flesh of the paupers,

What they drink is the poor men's blood.

He struck hard at the heartlessness of the powers that be:

The lords are wild with wealth and might, They ignore the poor people's plight;

Immersed in selfhood which is blight, Their hearts are shorn of charity. 
Yunus Emre also lambasted the illegitimate acquisitions of hypocrites who pose as men of high morals:

Hypocrites claim they never make a gain

Through any means which might be illicit.

The truth of it is: They only refrain

When they are certain they cannot grab it.

In poem after poem, he denigrated the orthodox views and the strict teachings of the pharisees:

The preachers who usurp the Prophet's place

Inflict distress and pain on the people.

Better than a hundred pilgrimages

Is a single visit into the heart.

Denouncing the zealot who preached submission to a Gof of punishment, Yunus Emre celebrated the love of a Gof of mercy and compassion:

True love is minister to us, our flock is the inmost soul;

God's face is our Mecca, and our prayers are eternal.

Many of Yunus Emre's fundamental concepts are steeped in the sufi (Islamic mystic) tradition, particularly as set forth by the 13th Century philosopher and poet Mevlana Celaleddin Rumi who, although he lived in Anatolia, preferred the legacy of Persia in cultural and linguistic terms. Like the medieval authors and thinkersin Europe who set aside their national languages in favor of Latin, Mevlana chose Persian as his vehicle of expression. Bu Yunus Emre, like Dante, preferred the vernacular of his own people.

Mysticism is based upon a monistic view of divinity. It holds, unlike Islam's central dogma, that man is not only God's creation but also God's reflection. Man is God's image, and yearns to return to God's reality from craving for union with God, and lives in a tragic plight of exile. The return to God is posssible not through physical death, but through love wbich purifies the soul.

The dogma claims that God, who created the earth and human beings, is outside of the world and unlike his creation. But the sufi view holds that God is inclusive of the universe, there is no dichotomy between God and mannothing in the universe has existence independent of Gof, all is God's revela- 
tion or reflection. The central doctrine of rufism is Vahdet-i vïcut (the unity of existence).

The mystic thinks of God as Kemal-i mutlak (absolute perfection) and as Cemal-i mutlak (absolute beauty). Thus, for the mystic, spiritual attainment goes together with an aesthetic sence, an infatuation with divine and earthly beauty. God himself is conceived of as having $A s ̧ k-\bar{i} z a t i$ (self-love) and, in terms of one of the elements of the mystic view of the creation of the world, God was motivated to create the universe and man as a mirror in which he could see the images of his own perfect beauty. Hence, it is a duty for the mystic to love God, and to become, through love, the perfect man. Yunus Emre's vision of life is "omnia vincit amor" (love conquers all). It is a sense of total love, love embracing all of life:

\section{Wherever I look see God's face}

He also revels in the beauty of the world. He has the typical humanistic joy of life:

This world is like a bride

Adorned with green and red

Yunus Emre's poetry has a unitary vision of man and nature. For him, nature is a feast in which all men take part and mankind means brotherhood:

$$
\begin{aligned}
& \text { The world is my true ration } \\
& \text { Its people are my nation. }
\end{aligned}
$$

Yunus Emre's humanist vision sought to enrich human existence and to ennoble it by liberating man from dogma and by placing him in a relationship of love with God. His poetry is intensely human in its sentiments and humane in its concern for the plight of deprived people. He was the first-and the most successful- poet in Turkish history to create the "aesthetics of ethjes."

In an age when hostilities and rifts and destruction were still visible everywhere, Yunus Emre was able to give expression to an all-embracing love of humanity and to his concepts of universal brotherhood which transcended all schisms and sects:

For those who truly love God and his ways All the people of the world are brothers. 
The man who doesn't see the nations of the world as one

Commits heresy even if the pious claim he is a saint.

Yunus Emre's humanism is based on international understanding which transcends all national and sectarian divisions:

Mystic is what they call me,

Hate is my only enemy;

I harbor a grudge against none.

To me the whole wide world is one.

Seven centuries ago, Yunus Emre attained to the apogee of the intellectual tradition of Turkish humanism and gave some of the most eloquent specimens of humanitarianism, both of which had their renascence in Turkish poetry, in explicit terms, in the latter part of the 19th Century and suffused the work of many Turkish poets, as a spiritus movens, since the 1920 s. But few poets in Turkey or elsewhere have ever excelled in the poetry of humanism in the same magnitude that characterizes the art of Yunus Emre:

Come let us be friends

And make life easy on ourselves,

Let us love and let us be loved,

No one shall inherit the earth.

\section{B I B L I O G R A P H Y}

\section{In Turkish}

Alıçlı, Sırrı: "Yunus Emre'de İnsanlık", Türk Yurdu, Cilt 5, Sayı 319, Ocak 1966, ss. 117-120.

Araz, Nezihe: Dertli Dolap (Yunus Emre'nin Hayat Hikâyesi), İstanbul, Fatiş Yayınevi, 1961.

Cumbur, Müjgân: Yunus Emre'nin Gönlü, Ankara, Yunus Emre Derneği Yayınları No. 3, 1959.

Cumbur, Müjgân: "Yunus'tan Bir Şiir ve Beşerî Aşk", Türk Yurdu, Cilt 2, Sayı 2, 1960.

Evliyaoğlu, Gökhan: Anadolu'nun İç Aydınlığı Yunus Emre, İstanbul, Yağmur Yayıları, 1963. 
Eyuboğlu, Sabahattin: Yunus Emre'ye Selâm, İstanbul, Çan Yaymları, 1966.

Gölpınarlı, Abdülbaki: "Yunus Emre", Türk Dili (Türk Halk Edebiyatı Özel Sayn), Sayı 207, Ankara, Aralık 1968, ss. 376-384.

Gölpınarlı, Abdülbaki: Yunus Emre - Hayatı, İstanbul, İkbal Kitabevi, 1936.

Gölpınarlı, Abdülbaki: Yunus Emre - Hayatı, Sanatı ve Şiirleri, İstanbul, Varlik Yaymevi, 1957.

Gölpınarlı, Abdülbaki: Yunus Emre Divanı, İstanbul, Ahmet Halit Kitabevi, 1943-1948.

Gölpınarlı, Abdülbaki: Yunus Emre, Risâlat al-Nushiyya ve Divân, İstanbul, Eskişehir Turizm ve Tanıtma Derneği Yaym 1, 1965.

Gölpınarlı, Abdülbaki: Yunus Emre ve Tasavvuf, İstanbul, Remzi Kitabevi, 1961.

Halman, Talât: "Yunus'un Yedinci Yüzyllı", Milliyet, 18 Ocak, 1970.

Karakoç, Sezai: Yunus Emre, İstanbul, Bedir Yayınevi, 1965.

Köprülü, Fuad: Türk Edebiyaiında Ilk Mutasavvıflar, Ankara, Diyanet İşleri Başkanlığı Yayınları (İkinci Basım), 1966, ss. 155-307.

Kenter, Halim Baki: "Her Asrın İnsanı Yunus", Selâmet Dergisi, Cilt 2, Sayı 14, 1963.

(Ongun), Cemil Sena: "Yunus Emre'nin Felsefesi", YTürk Yurdu, Cilt 5, Sayı 319, Ocak 1966, ss. 62-67.

Saner, Cemalettin: "Yunus Emre: Tasavvufta ve Millî Ruhtaki Önemi", Türk Yurdu, Cilt 5, Sayı 319, Ocak 1966, ss. 123-127.

Sofi Huri: "Garbın Gözüyle Yunus Emre”, Türk Yurdu, Cilt 5, Sayı 319, Ocak 1966, ss. 88-91.

Tanpınar, Ahmet Hamdi: "Yunus Emre", Edebiyat Üzerine Makaleler, İstanbul, Millî Eğitim Bakanlığı Devlet Kitapları, 1969, ss. 139-142.

Topçu, Nurettin: "Yunus Emre'de Vahdet-i Vücut", Türk Yurdu, Cilt 5, Sayı 319, Ocak 1966, ss. 84-87.

Toprak, Burhan: Yunus Emre Divanı, Türkiye İ ş Bankası Kültür Yayınları, 1966.

Yurdu, Cilt 5, Sayı 319, Ocak 1966, ss. 21-23. 


\section{In Other Languages}

Arzık, Nimet: Anthologie de la chanson populaire turque, Ankara, Ayyldız Matbaas1, 1963.

Arzık, Nimet: Anthologie de la poésie turque, Paris, Gallimard, 1968.

Bazin, Louis: "La littérature turque", Histoire des littératures, Paris, 1955.

Beale, W.; trans: Yunus Emre poems in Ahmed Adnan Saygun's "Yunus Emre Oratorio", Programme of the United Nations Concert presented by the President of General Assembly, November 25, 1958.

Birge, John Kingsley: The Bektashi Order of Dervishes, London, Luzac and Company, 1937

Birge, John Kingsley: "YYunus Emre: Turkey's Great Poet of the People", The Macdonald Presentation Volume, Princeton, N. J., Princeceton University Press, 1933.

Bombac1, Alessio: Storia della letteratura turca, Milan, 1956.

Ecevit, Bülent: "Yunus Emre", appendix to Modern Turkish Poetry, New York, Turkish Information Office, undated.

Eyuboğlu, Sabahattin: "Poésie populaire turque", Dialogue, İstanbul Üniversitesi Fransız Filolojisi, Sayı 4, 1965.

Gibb, E. J. W.: A History of Ottoman Poetry, Vol. 1, London, Lowe and Brydone, 1900.

Halman, Talât Sait: "Man, Love and God in the Poetry of Yunus Emre", Turkish Digest, Washington, D. C., Vol. 6, No. 2, February 1970.

Halman, Talât S.: "Turkish Humanist Poetry", Gazette, Zürich, October 1970.

von Hammer-Purgstall: Geschichte der Osmanischen Dichtkunst, Pesth, 1836-1838.

Kaplan, Mehmed: "La joie de Yunus Emre", Dialogue, İstanbul Úniversitesi Fransız Filolojisi, 1953.

MacCallum, Lyman: "Yunus Emre", Muslim World, Vol. XXXVI., April 1946.

Regnier, Yves: "Quatre poèmes", L'arche, Mars-Avril 1946, Ndlr Edition de Paris.

Regnier, Yves: Poèmes - Yunus Emre, Paris, GLM, 1949. 
Regnier, Yves: Le divan par Younous Emre, Paris, Gallimard, 1963.

Schimmel, Annemarie: "Yunus Emre", Numen, Vol. VIII, Fasc. 1, January 1961.

Schimmel, Annemarie: Drei türkice Mystikes: Yunus Emre, Kaygusuz Abdal, Pir Sultan Abdal, Mitteilüngen dee Deutsh-Türkischen Gesellschaft, Bonn, 1962.

Schimmel, Annemarie: Lyric des Ostens, Müchen, 1952.

Sofi Huri: "Yunus Emre-In Memoriam", Muslim World, Vol. XLIX, April 1959.

Walsh, John R.: "Yunus Emre: A 14 th Centuary Turçkish Hymnodist", Numen, Vol. VII, Fasc. 2-3, December 960.

NOTE:

In September 1971, Akbank will sponsor an international symposium on Yunus Emre's thought and poetry. About ten scholars from abroad, including Prof. Annemarie Schimmel and Dr. Barbara Flemming (West Germany), Prof. Louis Bazin (France), Dr. Emin Reyahi (Iran), Prof. John R. Walsh (England), Prof. Andreas Tietze and Prof. Talât Sait Halman (USA), are expected to attend the symposium which will take place in Istanbul. The papers presented at the symposium will be published by Akbank in a special volume. Akbank will also publish four volumes featuring the humanistic poetry of Yunus Emre - an anthology in Turkish, German translations by Annemarie Schimmel, French translations by Tahsin Saraç, and English translations by Talât Sait Halman.

Talât Sait Halman is on the faculties of Princeton University and New York University. In Turkey he regularly contributes to leading literary magazines and has published books featuring his translations of Shakespeare's Sonnets, William Faulkner's fiction, Eskimo poetry, selected poems of Wallace Stevens, etc. In addition to a collection of his own poems. In the United States, he has contributed to The Encyclopaedia of Poetry and Poetics, Reader's Encyclopaedia of World Literature in the Twentieth Century, Encyclopaedia of Islam, Yearbook of Comparative Literature, The New Leader, Tge Middle East Journal, Literature East and West, The Literary Review, Books Abroad, etc. His translations of Selected Poems by Fazll Hüsnü Dağlarca were published in book form by the Pittsburgh University Press in 1969. In 1971 Corinth Books Will publish his translations of selected poems of Orhan Veli Kank under the title of $I$ am Listening to Istanbul. He has given lectures on Yunus Emre's humanist poetry at New York's Carnegie International Center, Harvard Universty, and Indiana University. 